\title{
Constructing the Pacific Hut
}

\author{
Mike Austin and Jeremy Treadwell
}

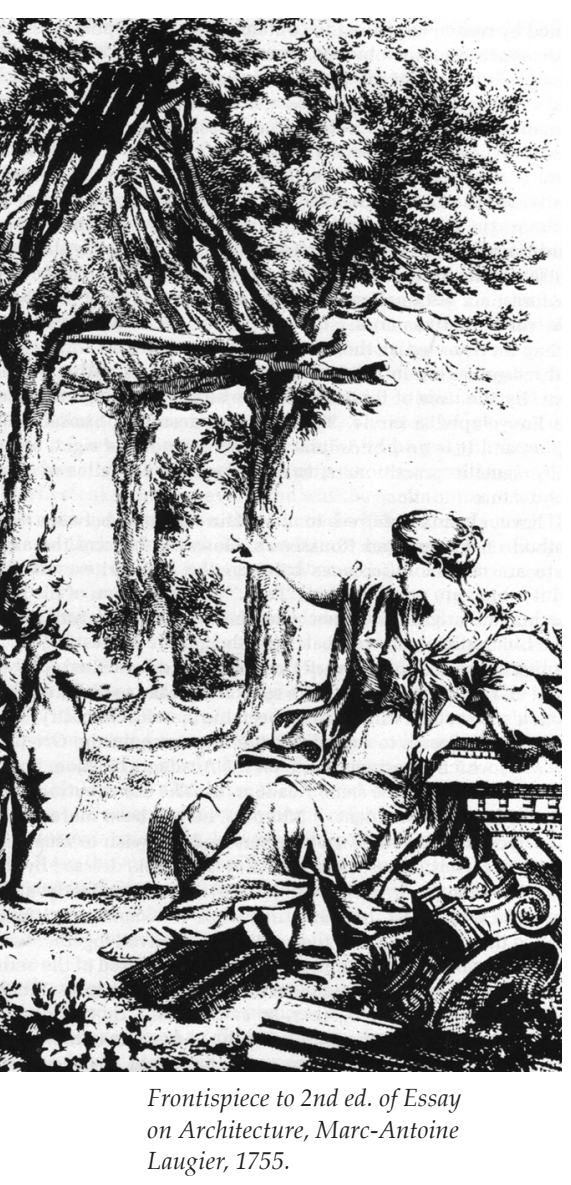

Building a primitive hut is not quite as simple as Laugier's well-known illustration would have us believe. The arrangement requires four judiciously placed, identical, trees to provide its support and, more importantly, its lateral stability. This is as far-fetched a fantasy as any utopian sky-hook, but we are diverted from appreciating this by the figures in the foreground pointing to the hut as the origin of architecture that is activated by this symposium. The wider question relating to the issue of origin is, what kind of knowledge systems are brought to bear on it? Traditionally, such questions are framed by considerations of environmental determinism, cultural signification and history.

Tectonic issues are often neglected, but the instability of architectural origins becomes immediately apparent to anyone trying to build even the most primitive of huts. Somehow the supporting posts have to be stabilised, which is often achieved by burying them in the ground. However the vertical cantilever of the posts is usually not enough to resist the outward thrust of the rafters. The Pacific solution to the spreading posts is to support the ridge beam itself on posts, thereby eliminating the lateral load. The ridge beam is the ubiquitous sign of the Pacific hut. This paper will consider some examples of the ridge beam and its supports (or lack of) on the houses of just two Pacific Island nations - Samoa and Papua New Guinea.

Rykwert discusses the situation at Ise temple ("perhaps the best known of Japanese religious buildings") towards the end of On Adam's House in Paradise: "the oddest feature is that the roof is not supported on the walls ... [instead] ... the ridge beam is independently carried by two large columns which go directly into the ground" (Rykwert 1981: 178). He also points out that the post that is housed on the unused site at Ise is "shin-no-mi-hashira (literally 'the august column of the heart')" (Rykwert 1981: 177). This ridge-beam support is given all sorts of significances in the Pacific. In Polynesia the post is often identified with the authority of the chief, also as a mast, making the ridge the keel of the upturned boat. In the Māori meeting house the main supporting post is the pou tokomanawa - the heart of the anthropomorphic house.

Wallace and Irwin say the prehistoric Māori house "could be seen as being built from the top down" (Wallace and Irwin 1999: 80). They suggest that the technology of house construction derives from canoe-building traditions (Wallace and Irwin 1999: 84). Māori sometimes used old canoes as a ridge (Neich 2001). Consequently, houses in Oceania tend to be tied down rather than built up as with the compressive earth-based technologies of walls and arches. In the Pacific, when the rafters cross at the ridge, there is generally an upper ridge as a constructional device to secure the top ends. The upper ridge is sometimes tensioned down on to the ridge beam itself, which pre-stresses the rafters, increasing their spanning capacity and reinforcing the upside-down-boat cross-section. 
The middle section of the Sepik river system in Papua New Guinea is separated by mountains from the northern coast, to which the river drains. Several groups live in the Sepik but there are differences in the architecture between those who live on the river (the Iatmul) and the people who occupy the mountains (referred to generally as the Maprik area). There have been forays into the region for over a century by well-known commentators such as Gregory Bateson and Margaret Mead, and the Sepik area has been described as "excessive" in its cultural elaboration and aesthetic production. In the early 1980s an anthropological conference on the Sepik was held, followed by the publication of Sepik Heritage: Tradition and Change in Papua New Guinea. In this there is frequent reference to the houses, particularly the ceremonial or 'spirit' houses (haus tambaran) which, as Ross Bowden says, "... constitute some of the most impressive forms of vernacular architecture not only in the Pacific region but in the entire tribal world" (Bowden 1990: 480).

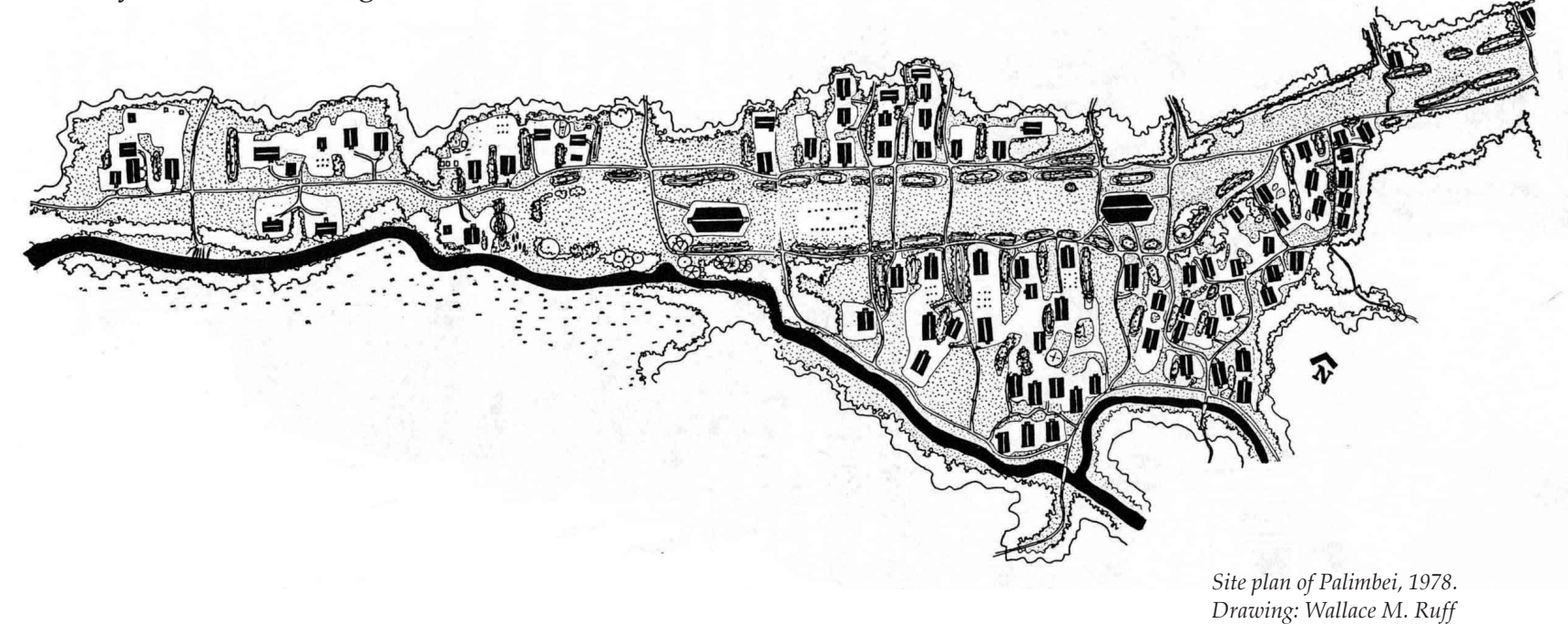

Opinion on whether the ceremonial houses are elaborations of the domestic houses seems divided among the anthropologists. Certainly the ceremonial houses are much bigger than the domestic houses. The haus tambaran and the dwellings are differentiated within the settlement patterns. "The important differences, socially and structurally, between the men and women who compose clan settlements can be correlated symbolically with the physical layout of villages." (Bowden 1990: 481) Men constitute the residential cores of a group whereas women occupy the periphery (Bowden 1990: 482). On the banks of the Sepik river, the Iatmul people site their haus tambaran parallel to the river, sitting centrally in its open space dancing ground while the domestic houses are at right angles to the river. Both buildings are elevated on piles because of regular floods.

The characteristic saddle-shaped roof of the haus tambaran is made by propping the upper ridge at each end of the building. The prop is known as the meri post, which has at its lower end a carved figure of a woman. (Meri is the word for woman in tok pisin - the lingua franca). The access ladder to the upper level goes up between the legs of the carved meri. The meri in turn sits on a horizontal beam supported on the cantilevered ends of the wall plates, which are themselves cantilevered beyond the supporting posts. These supporting posts are usually richly carved and are often constructed (as are the canoes) from trees salvaged from the river. At their bases the ridge posts have the orator's stool, a significant location in the house where the men spend their days (and nights) in important discussions. 
Ceremonial house called Paiyembit, 1978. Drawing: Wallace M. Ruff

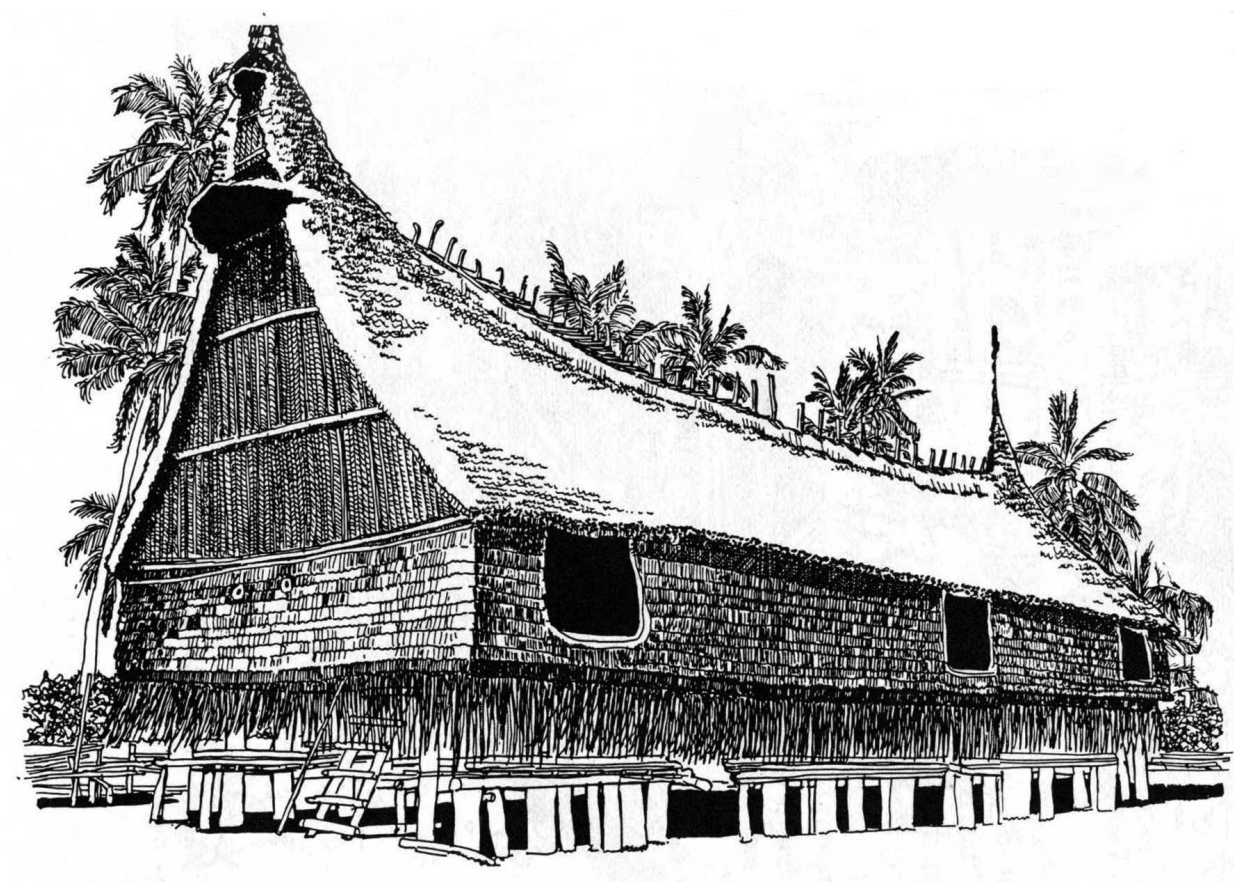

The upper level is used for storage, and for secret initiation ceremonies where the presence of the tambaran is announced by flutes and bullroarers. The secret is, of course, that it is the men who play these instruments. The floor (as again is characteristic with Oceanic houses) is a quite separate structure - supported on its own system of posts and beams, and again using cantilevers to increase the load-bearing capacity of horizontal members. The outer skin of the house is hung off the roof structure.

By contrast the haus tambaran in the Maprik area has no floor, and the settlement pattern consists of hamlets sited on mountain ridges and organised around living courtyards. The houses here appear quite different to the Iatmul, their richly painted bark facades towering above the courtyards. Forge (1971) and Tuzin (1980) have each described the construction of these houses for the two main groups in the area (Arapesh and Abelam respectively) in some detail.

First the heavy wall plates that slope to the rear both in plan and section are erected on their supporting posts buried some three metres into the ground, using bamboo poles to excavate the holes. The ridge is similarly massive and raised (usually at dawn) on temporary supports - a major ritual and structural undertaking (said to be carried out by the tambaran). Once the roof framework of slender bamboo has been installed it acts as a diaphragm, and the ridge pole supports are removed, "... with the terrific weight of the ridgepole being borne entirely by the rafters the latter bow very slightly. The house takes on a slightly 'hunched' appearance." (Tuzin 1980: 151-152)

The question is of course why the Maprik ridgepole needs to be so massive when in fact it is the building which supports the ridge pole rather than vice versa. This support can be compared to the competitive display of yams, each in their own netting hammock, the growing of which is a principle activity of the men and where size is the issue. Both ridge-pole and yam are of course phallic and there is apparent sexual imagery in the elaborate hooded treatment of the end of the ridge pole which is similar in both Iatmul and Maprik houses. It is also said, however, that the people themselves deny this association (Forge 1974: 306).

This might be a reason why some anthropologists have gone to considerable lengths to argue that the Maprik houses in the mountains are the same as the Iatmul houses down on the river. "Although Abelam and Iatmul ceremonial houses do not look alike, they are homologous at a more abstract level; that is 


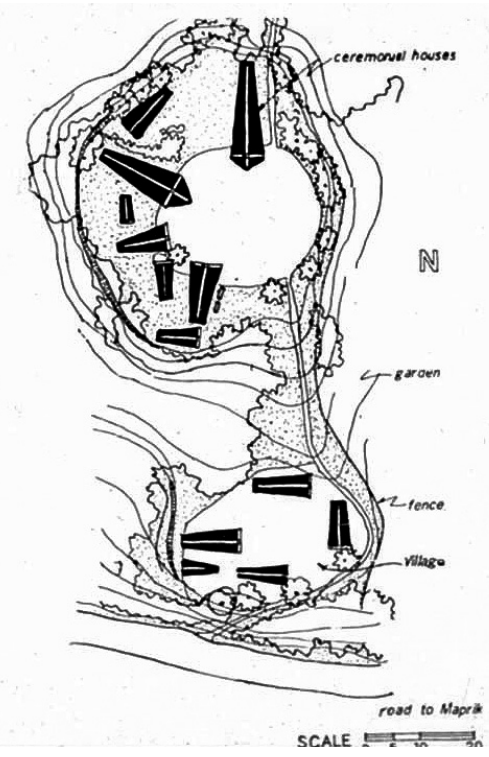

Site plan of Mambauro village (nd) Drawing: Wallace M. Ruff

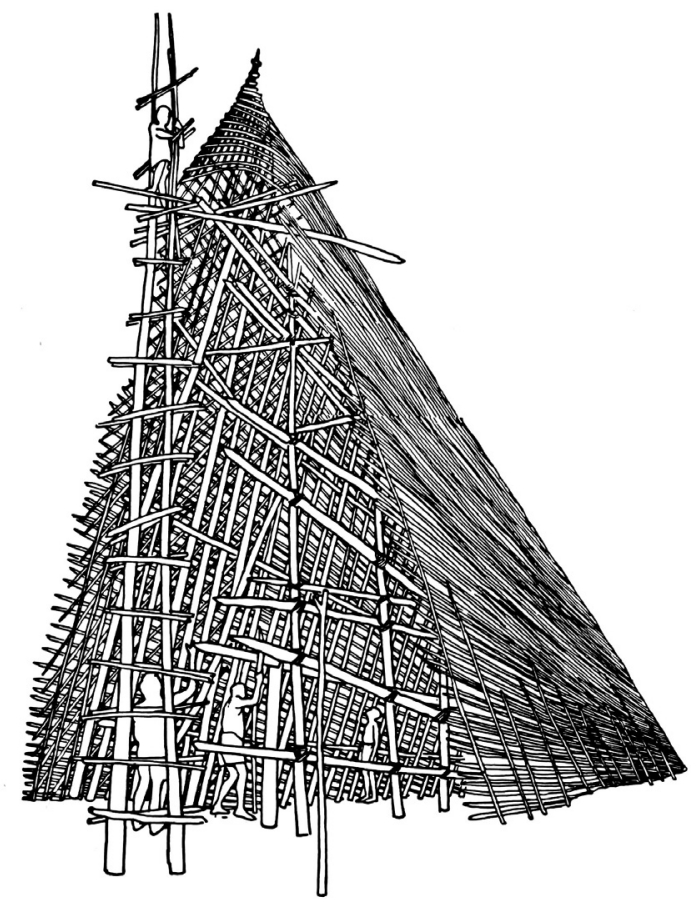

Maprik ceremonial house under construction. Drawing: Wallace M. Ruff from a 1950s photo by Anthony Forge

their symbolic functions and ritual forms are virtually identical." (Forge 1990: 166) The two locations are less than 50 kilometres apart, and the two people are part of the same language family, in a country that has over 700 separate languages. However we are being asked to accept that a house on the ground with a triangular plan, no walls and a sloping ridge pole is the same as a saddle-roofed, rectangular house on stilts.

We have no space here to go into the tortuous arguments proposing this, except to say this ridge beam is argued to be one of the important similarities. What is certainly different is that in one case the ridge post is a significant location, and in the other there is no ridge post, leaving an empty interior. The gable-end treatments are also different, with magnificent painted bark facades in the Maprik area, and mask screens hanging off the saddle roof for the Iatmul. The origin for both is claimed to be a house on the plains between mountain and river, a story which again is too lengthy to go into. What is certain is that there have been complex migrations of people and architectural ideas, as well as means of construction, associated with this version of the Pacific hut.

We now shift across the Pacific to Samoa (where, incidentally, Margaret Mead began her career) to build a discussion about the fale Samoa in these terms. This discussion proceeds on the basis of the scholarly work of others but also from experience in the construction of a fale Samoa. As in the physical building this discussion will be structured by key tectonic elements and operations: the ridge pole, the ridge support and the closure of the gable end.

Evidence shows pre-historic housing in Samoa to have been variable, both across sites and within topographical regions. Stone pavements, perimeter kerbing and the geometries of postholes constitute the evidence of buildings, sufficient to demonstrate that houses consistently differed both in size and tectonic strategy (McKinlay 1974: 28). We also find that this variability of house form extended into the nineteenth and twentieth centuries.

In his 1930 book Samoan Material Culture, Te Rangi Hiroa (a.k.a. Peter Buck) lists and describes the full range of buildings he encountered: the canoe shed (afolau), the cook house (fale umu), the dwelling house (fale o'o) and the two types of guest house (fale afolau and fale tele). Underlying this fale taxonomy is a tectonic distinction by which these buildings are understood. The afolau is constructed without any vertical ridgebeam supports. Median posts would preclude the housing of 
Two canoe sheds and a long house in Tonga 1833. From: Durmont d'Urville, JSC, 1833 voyage de la Corvette Astrolabe Pt ll Pl 81, ATL Wellington NZ Neg 54013 1/2

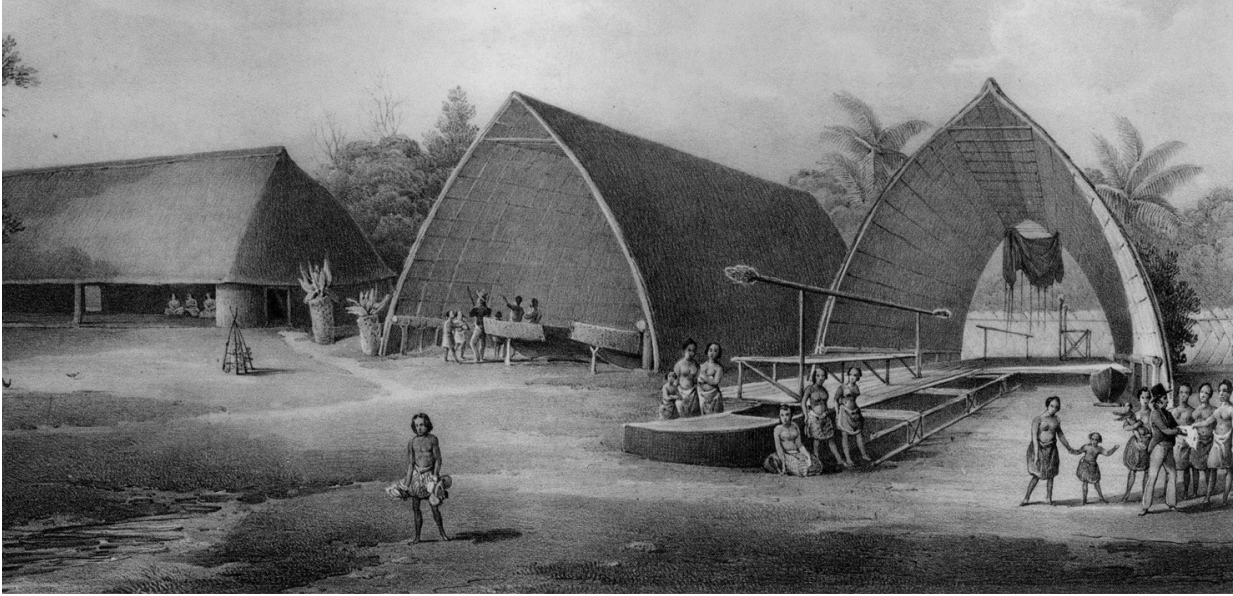

large, open-gabled canoe sheds and, in the background, the Tongan long house, the fale hau. From this image it becomes clear that both buildings feature the same long gable section and open interior space. The distinguishing feature between them is the round-ended tala on the fale. The inference might be drawn that the afolau and fale share ancestry, but visual similarity alone is superficial. This question might be further traced through tectonics and representation.

In his introduction to Samoan buildings, Buck wrote, "In describing the various types of Samoan houses, it is better to follow their natural evolution and work upward from the simplest form to the highly organised guest houses" (Buck 1930: 10). Buck was also trained as a medical doctor, a discipline structured by Darwinian thought, in which species evolved through favourable mutation and natural selection, from simple to complex structures.

In this context, the fale umu, the simplest of houses, contained, for Buck, the preconditions for development into the larger complex houses. Of its tala and the single curved purlin (fau) he wrote:

The single fau is in one piece, but in order to take the curve the pole is thinned by splitting of a section on either side, such a purlin is termed a fau sasae. The fau sasae is important in that it forms the precursor of the very elaborate curved purlins used in the guest house. (Buck 1930: 15)

Acting as it does to stabilise the rafters as they fall in an array from the ridge end, the fau sausae becomes for Buck the 'origin' of the curved tala.

There is however no inevitability that such a sequence took place. In order for this thinking to be convincing, it becomes necessary to believe only in a onedirectional functional model of development. It is, of course, equally possible for a feature to be retrospectively applied to a building because of any number of cultural or functional priorities, and the split fau saesae could be an approximation to the fau. Functional determinism as an explanation for the round end of the fale is also unsustainable in the face of a huge diversity of gable-end strategies elsewhere in the Pacific and even in Samoa. Further scrutiny of the tala of the larger fale seems to suggest that there are other than the traditional structural priorities of continuity and stability.

Buck's drawings of the junction between the tala and the itu show that the junction is achieved by connecting the thinnest of the thatching astles to the much reduced rafter element. The large curved purlins (fau) transmit no direct load 
through major structural members of the itu. It is as though the two sections of the building were simply stitched together. This junction is also a delineation between builders, a signature of identification and limitation. Buck comments on this 'dotted line': "The weakness of Samoan houses is the joint of the rounded ends to the end rafters of the middle section. There is danger that the wind will lift the thatch directly and take the roof with it." (Buck 1930: 82)

It is possible, however, that the fale still has some commitment to mobility. German anthropologist Augustin Kramer wrote of the tala, "Next to this centre part on each side is the round part of the tala which however is attached so loosely that it can be removed at any time which is very important in transporting such houses." (Kramer 1994-5: 270) There is an accompanying image of Samoans carrying a tala past Kramer's front gate. Because, elsewhere in the Pacific and even in Samoa, gable ends are routinely closed off using straight members in various configurations, and because of the detachability of the tala from the itu, an inference might be drawn that other systems of knowledge are implicated, both in the potential mobility of the tala and its constructional relationship to the gable end.

Edward Smith Handy observed the construction of a fale afolau in Samoa some six years before Buck. He described a small timber element fitted to complete the ridge beam at the apex of the itu gable and its junction with the top of the tala. "Moamoa", he wrote, "were carved in symbolic representation of the moon and the stars." (Handy 1924: 8)

Stars make another appearance in the tala. In a description of builders' guild marks, Buck pointed to an inscription of stars on a narrow timber batten standing vertically at the mid-point of the fau lalo (lowest and horizontal element of the tala) and behind the ascending arcs of the fau. Although Buck dismisses the significance of this as being of modern origin, it is curious that star symbols, in this context, combine to construct an arc from the midpoint of the fau lalo, to its zenith at the peak of the gable and the moamoa. Latent within the structure, but perhaps more compelling, are the arcs of the rising purlins of the tala, each lifting in succession from the 'horizon' of the fau lalo, like stars rising in sequence before the progress of the canoe and the rotation of the earth.

In this sense the tala is the mobile element that reinvests the voyage and its progress by stellar navigation. It also may be read as an activated cosmological model, an association between roof and sky readily made elsewhere in the Pacific (Budgett 2007: 39; Maude 1980: 5).

While the sectional shape of the itu recalls the hull of the canoe, the entwinement between architecture and canoe proliferates elswhere. In Kramer's translation of the constructional sequence of the large catamaran we learn that before the carpenter issues instructions to begin building the canoe, he instructs the builders to build the house that the canoe will be built in. After the keel blocks are placed in the completed afolau, the keel is laid underneath and in line with the ridge pole, Kramer records, "then the builders take a round pole and stand it upright against the ridge beam of the house at the same time placing the other end on the keel" (Kramer 1994-5: 291). The ridge pole of the house stabilises the keel of the boat as the planking is scribed to fit. Momentarily architecture and boat become one again.

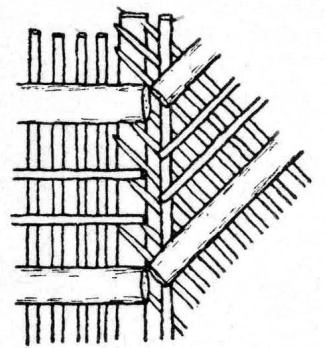

Junction between itu and tala (from Buck 1930: 53)
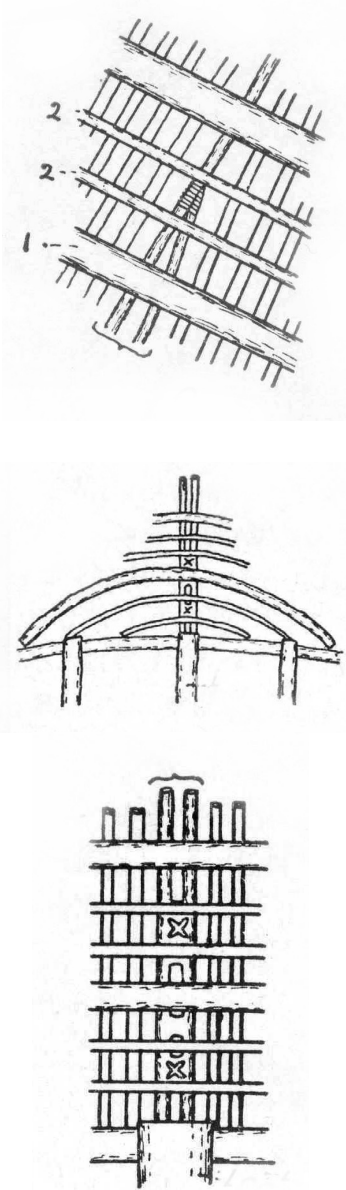

Central split rafter decorated with stars and fixed to fau lalo - in line with ridge and moamoa (from Buck 1930: 87) 


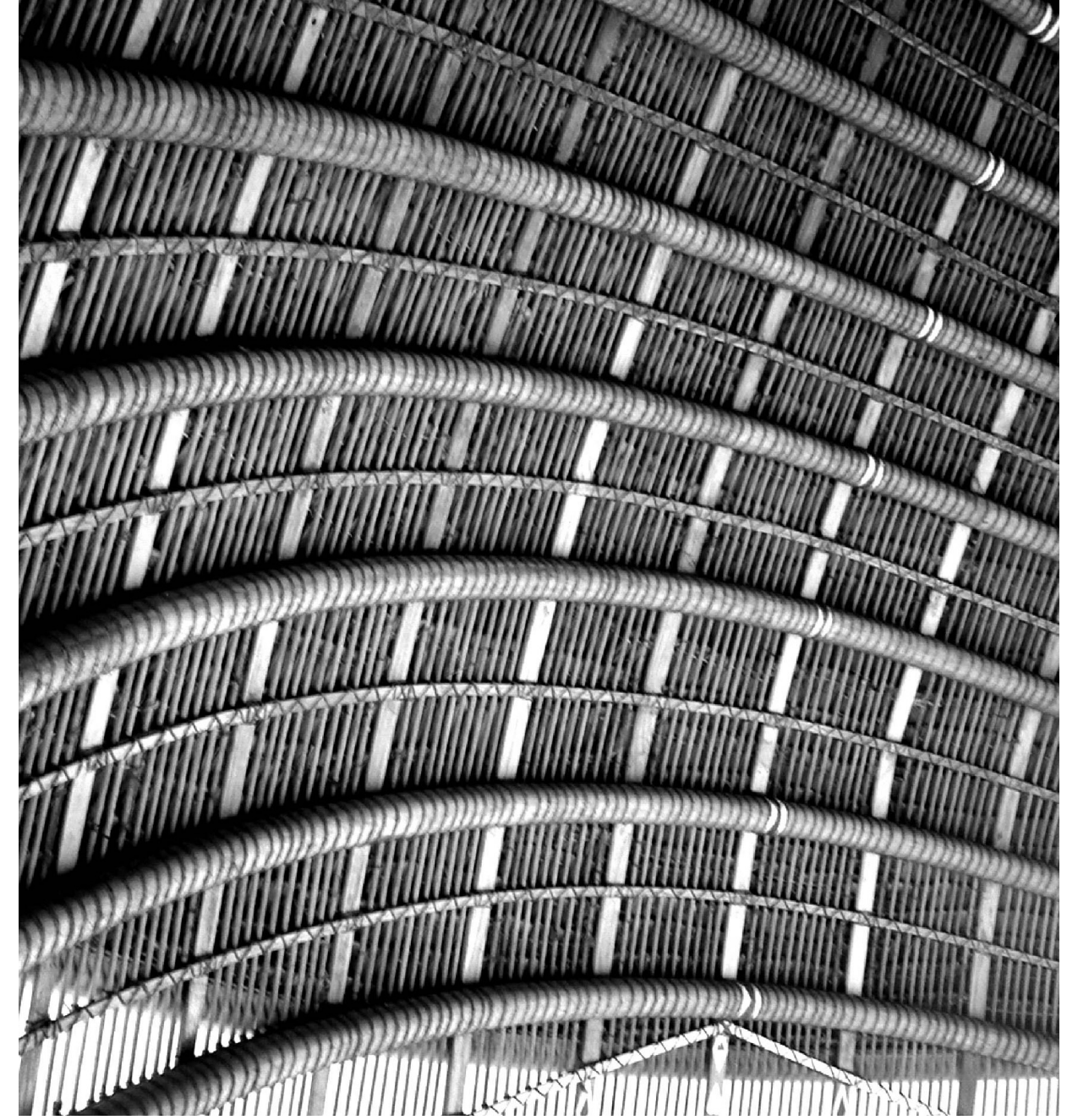

\section{Glossary}

\begin{tabular}{|c|c|}
\hline afolau & canoe shed \\
\hline fa'asoata & $\begin{array}{l}\text { method of supporting the ridgepole with curved rafters } \\
\text { alone, without any intermediate supporting post }\end{array}$ \\
\hline fale afolau & the long house - a fale built using utupoto construction \\
\hline fale o'o & the ordinary dwelling house \\
\hline fau & curved purlins used to support the thatch rafters in the tala \\
\hline fau sasae & a fau longitudinally split to enable it to curve around the tala \\
\hline haus tambaran & ceremonial or spirit house \\
\hline$i t u$ & the middle section of the fale, between the tala \\
\hline meri & woman in tok pisin \\
\hline moamoa & $\begin{array}{l}\text { a small timber element fitted to complete the ridge beam } \\
\text { at the apex of the itu gable and its junction with the top } \\
\text { of the tala }\end{array}$ \\
\hline pou tokomanawa & central ridge post in a Māori meeting house \\
\hline tala & the round end sections of the fale \\
\hline tok pisin & Pidgin, the lingua franca in Papua New Guinea \\
\hline utupoto & $\begin{array}{l}\text { the use of a tie beam to support king posts which } \\
\text { support the ridge pole }\end{array}$ \\
\hline wharau (Māori) & $\begin{array}{l}\text { a particular long house including a shed form built } \\
\text { over canoes }\end{array}$ \\
\hline
\end{tabular}




\section{References}

Barnes, S. and Green, R. (2008). From Tongan Meeting House to Samoan Chapel: A Recent Origin for the Samoan Fale Afolau. The Journal of Pacific History, 43(1), 7.

Beaglehole, J. (Ed.) (1967). The Journal of Captain Cook on his voyages of Discovery, vol. 3 The voyage of the Resolution and Discovery, pt. 2. Cambridge, 1967: 935.

Bowden, R. (1990). The Architecture and Art of Kwoma Ceremonial Houses. In Lutkehaus et al (Eds.), Sepik Heritage. Bathurst: Crawford House Press, 480-490.

Budgett, J. (2007). Coral Architecture of the Cook Islands. Unpublished dissertation for the degree of Master of Architecture, University of Auckland, 39, 47, 121.

Forge, A. (1971). Art and Environment in the Sepik. In Carol F. Jopling, Art and Aesthetics in Primitive Societies. New York: Dutton, 297.

Forge, A. (1990). The Power of Culture and the Culture of Power. In Luktehaus et al (Eds.), Sepik Heritage. Bathurst: Crawford House Press, 160-172.

Hiroa, Te Rangi (Peter H. Buck) (1930). Samoan Material Culture. Honolulu: Bernice P. Bishop Museum, Bulletin 75.

Handy E.S.C. and Handy W. C. (1924). Samoan House Building, Cooking and Tattooing. Honolulu: Bernice P. Bishop Museum, Bulletin 15.

Hauser-Schaublin, B. (1990). In the Swamps and on the Hills: Traditional Settlement Patterns and House Structures in the Middle Sepik. In Luktehaus et al (Eds.), Sepik Heritage. Bathurst: Crawford House Press, 470.

Ishisuki K. (1974). Excavation of Site SU FO 1at Falosa -A Lalo. In R.C. Green and Janet M. Davidson (Eds.), Archaeology in Western Samoa, Vol 2. (pp.36-57). Auckland: Bulletin of the Auckland Institute and Museum.

Kramer, A. (1994- 95). The Samoa Islands: an outline of a monograph with particular consideration of German Samoa 1865-1941. Auckland: Polynesian Press.

Lutkehaus, N. et al (Eds.). (1990). Sepik Heritage: Tradition and Change in Papua New Guinea. Bathhurst: Crawford House Press.

Maude, H.E. (1980). The Gilbertese Maneaba. Kiribas: Institute of Pacific Studies USP.

McKinlay, J. (1974). Excavations at Sasoa'a: The Historic period. In R.C. Green \& Janet M. Davidson (Eds.), Archaeology in Western Samoa, Vol. 2 (pp. 13-35). Auckland: Bulletin of the Auckland Institute and Museum.

Neich, R. (2006). Pacific Voyaging after the Exploration Period. In K.R. Howe (Ed.), Vaka Moana Voyages of the Ancestors: The Discovery and Settlement of the Pacific. Auckland: David Bateman.

Neich, R. (2001). Carved Histories: Rotorua Ngāti Tarawhai Woodcarving. Auckland: Auckland University Press.

Refiti, A. (2002). Making spaces: Polynesian architecture in Aoteoroa, New Zealand. In Sean Mallon and Pandora Fulimalo Pereira (Eds.), Pacific Art Niu Sila: the Pacific Dimension of Contemporary New Zealand Arts. Wellington: Te Papa Press.

Rykwert, J. (1981). On Adam's House in Paradise: The idea of the Primitive Hut in Architectural History. Cambridge (Mass.): MIT Press.

Tuzin, D. (1980). The Voice of the Tambaran: Truth and Illusion in Ilahita Arapesh Religion. Berkeley: University of California Press.

Wallace, R. and Irwin, G. (1990). A Kohika Wharepuni: House Construction Methods of the Late Pre-contact Māori. New Zealand Journal of Archaeology, vol. 21, 80. 